\section{$\longrightarrow$ —論}

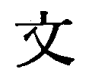

\subsubsection{7}

食違い角の大きい減速翼列の研究 ${ }^{(1)}$

（第 1 報，翼列試験方法の検討）

松木正勝 ${ }^{(2)}$, 高原北雄 ${ }^{(3)}$

食違い角の大きい減速翼列に関しては設計に用い得 るに十分な資料が欠除している．本研究は低速翼列風 胴によって二次元翼列としての性能を求め, 設計資料 を得ることを目的として行なったものである。

まず低速翼列風胴において, 二次元翼列性能を得る ための試験方法を検討した。すなわち翼列流入状態の 調節のためには翼列前スリットからの抽気量の選定方 法を検討し定めた。また上下壁の影響を除去するため に上下壁と上下翼間からの抽気を行なう必要がありそ の法を定めた。な打翼列間側壁からのはく離を防ぐ ためには多孔側壁を用いて抽気することが必要であ り，抽気量を決定するめやすには軸流速度比 $V_{2 a} / V_{1 a}$ $\doteqdot 1.1$ を用いることが適当である。

しかし二次元翼列としての性能を示す範柬を決定す るためには,この外に他の翼列性能をも考虑に入れて 総合的に判断すべきであり，その方法を定めた.

(1) 昭 35-10-14 第 38 期東京秋期檴演大会化おいて講演, 原稿受付 昭 36-2-6, 本論交は論交集 180 号任揭载の予定. (2), (3) 正員, 航空技術研究所.

533.691 .07

食違い角の大きい減速翼列の研究（1)

（第 2 報, 翼列試験結果とその検討） 松木正勝 ${ }^{(2)}$, 高原北雄 ${ }^{(3)}$

食違い角の大きい減速翼列に関しては設計に用い得 るに十分な餈料が尔除している。本研究は低速翼列風 胴によって二次元翼列としての性能を求め, 設計資料 を得ることを目的として行なったものである.

$S / C=1.2,1.0,0.7, C_{l o}=1.2,0.8,0.4,0.0, \xi=$ $45^{\circ}, 50^{\circ}, 60^{\circ}, 65^{\circ}$ の簳围において試験を行ない翼 列性能を得, 設計点を定めた.

これらの試験結果から食違い角と流出角の関係を明 らかにし, 流出角に対する翼列の負荷限界を定め, こ の場合の全圧損失係数, そり度, 揚抗比等を求めた。

(1) 昭 35-10-14 第 38 期東京秋期講演大会化颃いて講演, 原稿受付 昭 36-2-6，本論交は論文集 180 号に揭載の予定. (2)，(3) 正員， 航空技獄研究所.

$536.242: 532.582 .2$

\section{垂直加熱平板に沿う低レイノルズ 数の流れにおける熱伝達 ${ }^{(1)}$}

馬淵幾夫 ${ }^{(2)}$, 藤掛賢司 ${ }^{(3)}$

低レイノルズ数の流れと平行におかれた垂直加熱平 板の強制対流に及沽す浮力の影響を表わす近似理論を 展開し, 任意のプラントル数に適用できる簡易計算式 をえた。結果は

$$
\frac{N_{u x}}{2 \Psi_{1}^{1 / 2} R_{e x x^{1 / 2}}}=f\left(\frac{G_{r x}}{R_{e x}{ }^{2}}\right)
$$

なる形を有し， $\Psi_{1}$ はプラントル数の関数であるが， $f$ は実用上プラントル数に無関係であることを示し
抄

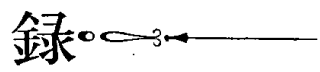

た.ここに $N_{u x}, R_{e x}, G_{r x}$ はそれぞれ局所的な又セ ルト数, レイノルズ数, グラスホフ数である. つぎに 前緣部に非加熱部分がある場合に適用できる実用的な 方法を提案した。李方ち上式を $G_{r x 0} / R_{e x 0^{2}}$ なる媒 体变数を導入し（脚符 0 は非加熱部分の長さ $x_{0}$ を長 さ基準にとったことを示す)， $N_{u x} / 2 \Psi_{1}^{1 / 2} R_{e x}{ }^{1 / 2}$ を $x / x_{0}$ について表わす修正を施した理論的予測の正しい ことが空気による実験により磪かめられたままた非加 熱部分のない場合流動形式は $G_{r x} / R_{e x}{ }^{2}<0.01$ で純強 制対流, $0.01<G_{r x} / R_{e . x^{2}}<16$ では混成流, $16<G_{r x} \mid$ $R_{e x}{ }^{2}$ では純自然対流として分類できこれはすべての プラントル数に対してもほほ成立することを示した。

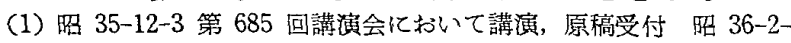
13，本論交は論交集 180 号江揭載の予定. (2)，(3) 正員，岐㔬大 学工学部.

536.2 : 532.135

発熱するスラリの熱伝達の研究 ${ }^{(1)}$

（第 1 報, 円管内完全層流）

$$
\text { 岐美格(2) }
$$

最近, 酸化ウランや酸化ナトリウムを, 水にスラリ 状に懸濁せしめ，然料として使用する均質炬の開発が 强く要望されてきている。この研究は, 上記の命題に ついて組織的に研究しょうとするもので, 第 1 報とし

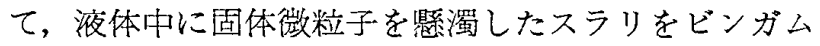
流体として取扱い(3)，これが均一に内部発熱しなが ら，円管内を層流して，速度分布も温度分布も完全に 発達した場合の熱伝達を解析した。理論解析結果によ ると, 円管内流体の温度分布, 混合平均温度扔よびヌ セルト数は, ビンガム流体の比せん半㺯ならびに壁面 における伝熱条件によって著しく影響されることがわ かった．結果は図表化して示し，またニュートン流体 や内部発熱しない場合と比較してある.

(1) 昭 36-3-17 関西支部第 36 期定時総会諈演会にわいて諈演, 原稿 受付 昭 36-4-1, 本論交は諭交集 180 年に揭載の予定. (2) 正員, 京都大学工学部. (3) J.A. Lane, はか, Fluid Fuel Reactors, (1958), Addison Wesley.

\section{$536.242: 532.529: 536.423$} 細線から噴霚気流への熱伝達 ${ }^{(1)}$

$$
\text { 武山 斌 郎(2) }
$$

水を空気で吹きちぎる噴霧気流の中に，電気的に加 熱された細線をおき, 細線から噴霧気流への熱伝達 が, (1) 気流の中の水之空気の流量容積比 $V_{w} / V_{a},(2)$ 気流の速度西るいは $R_{e}$ 数, (3) 細線の太さ $D \mathrm{~mm}$ と 噴霧の粒子堡 $d$ などによっていが影響されるか実 験を行なった。すなわち，噴霧気流への熱伝達は，対 流，核进騰，膜沸騰などの複雑な熱伝達を行なう水の 影響をうけて，水一の熱伝達と同じょうに，熱伝達率 と温度差との関係曲線に，いわゆる拔山点に対する極 大値と Leidenfrost 点に対する栖小值が現われる。 こ の極值の $N_{u}$ 数を，それぞれ $\left(N_{u}\right)_{n}$ おょび $\left(N_{u}\right)_{l}$ で表わし，極值を与える限界温萝美 $\left({ }^{\circ} \mathrm{C}\right)$ を，それて れ $(\Delta t)_{n}$ および $(\Delta t)_{l}$ とすれは，(1)および (2) 式 の実験式が得られる. 